\title{
The Effect of Serum IL-12 and TGF- $\beta 1$ Levels on the Prevalence of Atherosclerosis
}

\section{Serum IL-12 ve TGF- $\beta 1^{\prime}$ in ateroskleroz üzerine etkisi}

Hasan Ata Bolayir ${ }^{1}$

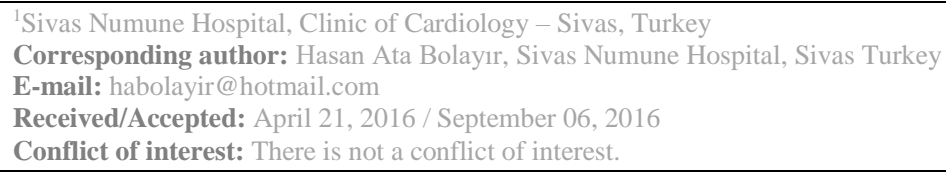

\section{SUMMARY}

Objective: It was observed that inflammation plays an important role in the progress of atherosclerotic vascular disease. This study is intended to indicate that, in oxidative and inflammatory medium, the course of the atherosclerotic process can be determined by the imbalance between Interleukin-12 (IL-12) and Transforming Growth Factor-beta1 (TGF- $\beta 1$ ) with a view to evaluate the effects of proinflammatory and anti-inflammatory cytokines on the course of the atherosclerotic coronary artery disease.

Method: 80 patients, who applied to cardiology outpatient clinic for typical chest pain, to whom coronary angiography was applied upon the detection of ischemia as a result of the effort test or myocardial perfusion scintigraphy conducted, and each of whom is exposed to at least one traditional risk factor for atherosclerotic coronary artery disease, were included to the study.

Findings: The patients were split into three groups as those, in whom atherosclerosis was not detected, those, for whom atherosclerosis prevalence is low, and those, for whom atherosclerosis level is high, according to the CASS 20 scores. It was observed that, as the atherosclerosis prevalence increased; average serum IL-12 levels $(3,33 \pm 0,15$ / 9,70 $\pm 0,22$ / 23,60 $\pm 0,46 \mathrm{pg} / \mathrm{ml})$ increased while average serum TGF- $\beta 1$ levels, $(32,1 \pm 0,59 / 18 \pm 0,28 / 6,74 \pm 0,42 \mathrm{ng} / \mathrm{ml})$, decreased. Conclusion: It was indicated that, in oxidative and inflammatory medium, the course of the atherosclerotic coronary artery disease was determined by the dominant cytokine on the intima of the related vascular segment.

Keywords: IL-12, TGF- $\beta 1$, atherosclerosis

\section{ÖZET}

Amaç: Ateroskelrotik vasküler hastalığın ilerleyişinde inflamasyonun önemli bir rol oynadığı izlenmiştir. Bu çalışma, oksidatif ve inflamatuar ortamda aterosklerotik coroner hastalığı gidişatında proinflamatuar ve antiinflamatuar sitokinlerin etkilerini değerlendirme noktasında interlökin 12 (IL12) ve transforming growth faktör beta 1 (TGF- $\beta 1$ ) arasındaki dengesizliğin belirlenebilmesini işaret etmeyi amaçlamaktadır.

Yöntem: Tipik göğüs ağrısıyla kardiyoloji polikliniğine başvuran 80 hastaya, efor testi ya da myocardial perfüzyon sintigrafisinin sonucu iskemi tespitine dayanarak coroner anjiografi uyguland. Aterosklerotik coroner arter hastalığı için geleneksel olarak en az bir risk faktörüne sahip hastalar çalışmaya dahil edildi.

Bulgular: Hastalar CASS 20 skorlarına göre aterosklerozu olmayan, düşük ve yüksek olmak üzere

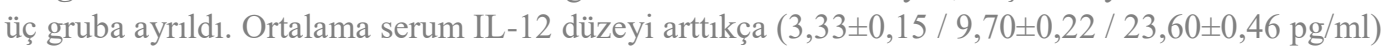

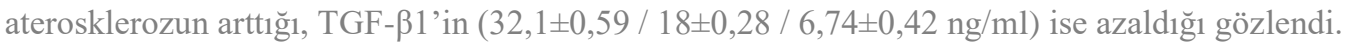


Sonuç: Oksidatif ve inflamatuar ortamda aterosklerotik koroner arter hastalığının gidişatının, ilişkili vasküler segmentin intimasındaki dominant sitokin tarafından tayin edildiği belirlenmiştir.

Anahtar sözcükler: Aterosklerozis, IL-12, TGF- $\beta 1$

\section{INTRODUCTION}

In the early years of the twenty-first century; fatalities associated with cardiovascular diseases accounted for roughly half of the overall fatalities in developed countries and for one fourth of the same in developing countries. ${ }^{1}$ Currently hypertension, diabetes mellitus, hyperlipidemia and smoking are considered as the traditional risk factors.

The traditional risk factors cause LDL oxidation, and contribute to the formation of oxidized LDL particles as well as the progress of the inflammation, leading to hs-CRP level to increase. The oxidative and proinflammatory medium so formed leads to the emergence in the medium of such cell groups, primarily including IL-12, that causes the secretion of various proinflammatory cytokines. As a result, atherosclerotic plaque forms and progresses.

A new cell group has been discovered recently, which is considered to be negatively affecting the atherosclerotic process, and which has been proven through animal testing to be suppressing the inflammatory response; and the cells in such group are referred to as $\mathrm{T}$ regulatory (Treg) cells. ${ }^{2}$ It was indicated that this cell group poses anti-inflammatory effect by way of contact inhibition or, as in most cases, by way of TGF- $\beta 1 .^{3}$

This study is intended to indicate that the sub-clinical inflammation, which emerges on account of such oxidative stress, could be determined by the imbalance between the proinflammatory cytokines (IL-12) and the anti-inflammatory cytokines (TGF- $\beta 1$ ) on the intima of the related vascular segment.

\section{MATERIAL AND METHOD}

For the purpose of this study; 80 patients, who applied to the Cardiology Outpatient Clinic of Gazi University Hospital for typical chest pain between December 2011 and December 2012, to whom coronary angiography was applied upon the detection of ischemia as a result of the effort test or myocardial perfusion scintigraphy conducted, and each of whom is exposed to at least one traditional risk factor for atherosclerotic coronary artery disease, were included to the study. The traditional risk factors for coronary artery disease were considered to be hypertension, hyperlipidemia, smoking and diabetes mellitus.

The requirements contemplated for inclusion to the study sampling were, without regards to whether being under medical treatment or not, for the patients' blood pressure arterial value at the time of application to be below $140 / 90 \mathrm{mmHg}$, for the serum LDL value of the same at the time of application to be below $100 \mathrm{mg} / \mathrm{dl}$, for the HbA1c value of the same at the time of application to be below 6.5, and the patients should not have smoked for the last 6 months.

Patients who were considered to have acute coronary syndrome, coronary artery diseases, decompensated 
cardiac insufficiency, serious valvular heart disease, chronic renal disease/insufficiency, active infection, autoimmune disease, malignancy or peripheral arterial disease were not included to the study.

The patients eligible for the study were applied a coronary angiography through Toshiba digital radiography system DFP-8000D device in line with the current scientific knowledge, and thereafter they were informed by the researcher physician about the study. Subsequently, printed informed consent forms were given to the patients for their review. The written consents of the patients, who agreed to participate in the study, were obtained. Following the coronary angiography, $10 \mathrm{cc}$ of blood was drawn from the sheath on the femoral artery; after allowing for 30 minutes for coagulation, it was then centrifuged at $4000 \mathrm{rpm}$ for 15 minutes. Then, the serums so derived were stored at $-80^{\circ} \mathrm{C}$ and were frozen in order for the measurement of IL-12 and TGF- $\beta 1$ levels of the patients at the time of their admission to the hospital.

Serum TGF- $\beta 1$ level was determined, using a Human TGF- $\beta 1$ instant Elisa Kit from Ebioscience/Bendermed Systems; and serum IL-12 level was determined, using a Human IL-12 Platinum Elisa Kit from Ebioscience/Bendermed Systems at the Central Laboratory of the Department of Biochemistry, Medical School,Gazi University.

The coronary angiography images of the 80 patients included in the study were evaluated by two observers. The atherosclerotic coronary artery disease prevalence levels of the patients were calculated using CASS
20 scoring system. ${ }^{4}$ The patients were divided into 3 groups, being those with CASS scores equal to 0 (patients detected to have normal coronary arteries), those with CASS scores equal to 1 to 3 (patients with low atherosclerosis prevalence), and those with CASS scores over 3 (patients with high atherosclerosis prevalence). The effects of the parameters to be studied on the formation of atherosclerosis and prevalence of coronary artery disease were evaluated on the basis of the serum samples collected.

The study data were evaluated using SPSS 15.0 statistics software package. The descriptive statistics were presented as a mean $( \pm)$, standard deviation, frequency distribution and percentage. Statistically significance level was accepted to be $p<0.05$. In addition to the descriptive statistics; KruskalWallis Tests and Spearman Correlation Test, being nonparametric test methods, were employed for the identification of the difference among the groups after evaluation through normality tests.

\section{FINDINGS}

According to the results of the coronary angiography applied to the patients; the patients with CASS 20 scores equal to 0 (detected not to have atherosclerosis) accounted for $33.8 \%$, those with CASS 20 scores equal to 1 to 3 (low atherosclerosis prevalence) accounted for $33.8 \%$, and those with CASS 20 scores $\geq 4$ (high atherosclerosis prevalence) accounted for $32.5 \%$ of the overall sampling. Table-1 compares the patients, as grouped according to CASS 20 scores, on the basis of basal characteristics and demographic characteristics. 
Table 1. patients characteristics according to CASS 20 scores.

\begin{tabular}{|c|c|c|c|c|}
\hline $\begin{array}{l}\text { The baseline characteristics } \\
\text { and demographics } \\
\text { Age }\end{array}$ & $\begin{array}{l}\text { CASS } 20 \\
\text { score }=0 \\
56 \pm 0,9\end{array}$ & $\begin{array}{l}1 \leq \text { CASS } 20 \\
\text { score } \leq 3 \\
55 \pm 1,1\end{array}$ & $\begin{array}{l}\text { CASS } 20 \\
\text { score } \geq 4 \\
57 \pm 0,9\end{array}$ & $\begin{array}{l}\mathrm{p} \\
\text { value } \\
0,50\end{array}$ \\
\hline Sex & $12(\% 44)$ & $12(\% 44)$ & $11(\% 42)$ & 0.87 \\
\hline \begin{tabular}{l|l} 
Female \\
\end{tabular} & $15(\% 56)$ & $15(\% 56)$ & $15(\% 58)$ & 0.87 \\
\hline $\begin{array}{l}\text { The average body mass index } \\
\left(\mathrm{kg} / \mathrm{m}^{2}\right)\end{array}$ & $34,5 \pm 0,6$ & $32,5 \pm 0,2$ & $35,3 \pm 0,8$ & 0.55 \\
\hline $\begin{array}{l}\text { The mean creatinine level } \\
(\mathrm{mg} / \mathrm{dl})\end{array}$ & $0.90 \pm 0,02$ & $1.1 \pm 0,02$ & $0.95 \pm 0,03$ & 0.88 \\
\hline $\begin{array}{l}\text { The mean ejection } \\
\text { fraction }(\%))\end{array}$ & $62 \pm 0,4$ & $60 \pm 0,4$ & $64 \pm 0,5$ & 0.85 \\
\hline The mean HbA1C level & $6.2 \pm 0.2$ & $6.4 \pm 0.1$ & $6.0 \pm 0.3$ & 0.54 \\
\hline \multirow{2}{*}{$\begin{array}{l}\text { The mean LDL level } \\
\text { The number of patient using } \\
\text { statin }\end{array}$} & $94 \pm 4.5$ & $88 \pm 5.2$ & $90 \pm 3.3$ & 0.24 \\
\hline & $10(\% 37)$ & & $9(\% 34)$ & 0.85 \\
\hline \multirow{2}{*}{$\begin{array}{l}\text { The number of patient using } \\
\text { antihypertensive drug } \\
\text { The number of patient using } \\
\text { oral antidiabetic drug }\end{array}$} & $10(\% 37)$ & $10(\% 37)$ & $9(\% 34)$ & 0.85 \\
\hline & $8(\% 29)$ & $8(\% 29)$ & $7(\% 26)$ & 0.83 \\
\hline
\end{tabular}

Furthermore, the average IL-12 level and the average TGF- $\beta 1$ level of the patients with CASS 20 scores equal to 0 were, respectively, $3.33 \pm 0.15 \mathrm{pg} / \mathrm{ml}$ and $32.1 \pm 0.59 \mathrm{ng} / \mathrm{ml}$; those of the patients with CASS 20 scores equal to
1 to 3 were, respectively, $9.70 \pm 0.22$ $\mathrm{pg} / \mathrm{ml}$ and $18 \pm 0.28 \mathrm{ng} / \mathrm{ml}$; and those of the patients with CASS 20 scores $\geq 4$ were, respectively, $23.60 \pm 0.46$ $\mathrm{pg} / \mathrm{ml}$ and $6.74 \pm 0.42 \mathrm{ng} / \mathrm{ml}$ (Table-2).

Table 2. The relationship between the levels of IL-12, TGF- $\beta 1$ and CASS 20 scores.

\begin{tabular}{|l|l|l|l|l|} 
CASS 20 score & 0 & $1-3$ & $\geq 4$ & $\mathrm{p}$ value \\
IL-12 level (pg/ml) & $3,33 \pm 0,15$ & $9,70 \pm 0,22$ & $23,60 \pm 0,46$ & $\mathrm{p}<0,01$ \\
TGF- $\boldsymbol{\beta 1}$ level (ng/ml) & $32,1 \pm 0,59$ & $18 \pm 0,28$ & $6,74 \pm 0,42$ & $\mathrm{p}<0,01$ \\
\hline
\end{tabular}

\section{DISCUSSION}

It is, currently, the recognized theory that the oxidative process invoked by traditional risk factors causes atherosclerosis. ${ }^{5}$ It was indicated that the oxygen and nitrogen metabolites that form throughout the oxidative process oxidized LDL particles from amino groups, whereby oxidized LDL particles formed. ${ }^{6}$ It was discovered that the LDL particles so formed were bonded to the Toll-like receptors and the receptors on macrophage and endothelial cells such as CD36 and LOX-1, and caused macrophage to activate (transform into foam cells) and proinflammatory cytokines to be secreted. ${ }^{7}$ It is known that, throughout 
the said oxidative and inflammatory process, hs-CRP rises and contributes to the process. ${ }^{8}$

A statistically significant correlation between the number of traditional risk factors posed and atherosclerosis prevalence was not observed in this study. More descriptively; the inflammatory process started by the oxidized LDL particles, which are deemed to form on account of the existence of any traditional risk factor, and subsequently, the emergence of proinflammatory cytokine prevalence would lead to the formation of more hs-CRP, which would lead to further LDL oxidation. When proinflammatory cytokine prevalence does not emerge, hs-CRP levels, and thus, oxidized LDL levels would drop. It was indicated by previous studies that hs-CRP played an important role in LDL oxidation. ${ }^{8}$ It can, accordingly, be suggested that, as proinflammatory cascade increases and, thus, hs-CRP and oxidized LDL levels rise; atherosclerosis poses a progress as a result.

Even though oxidative and inflammatory processes are critical elements of formation and progress of atherosclerosis; atherosclerosis formation would not take place in the event of the lack of formation of proinflammatory cytokine (primarily including IL-12) in the medium. The recent studies show that extremely large amounts of IL-12 m-RNA were detected in human atherosclerotic plaque formations. In fact, the animal testing shows that the atherosclerotic process progressed significantly faster in the mice infused with IL-12. ${ }^{9}$ In another animal study, it was observed that atherosclerotic process was precluded and even regressed in mice, which were administered IL-12 blocking antibodies. ${ }^{10}$ In fact, a strong positive correlation with statistical significance $(p<0.01)$ was observed between serum IL-12 level and coronary artery disease prevalence throughout the oxidative and inflammatory process, the formation of which was indicated, in the patients included in this study.

Had the atherosclerosis pathogenesis been limited to oxidative stress and proinflammatory cytokine secretion only; prevalent atherosclerosis would have been expected to form in all individuals with oxidative stress formation. The existence of an antiinflammatory cascade, which is activated concurrently with the proinflammatory cascade instigated by the oxidative process, has been discovered recently. The studies indicate that Treg cells as well as $\mathrm{T}$ helper cells emerge in the medium (in the intima of the related vascular structure) through the IL-12 that is secreted from the active macrophage ${ }^{11}$, and the said cell group secretes, particularly, TGF- $\beta 1$ and displays anti-atherogenic/ antiinflammatory activity. ${ }^{12}$ The animal testing conducted indicates that atherosclerosis is more prevalent in the mice, which were administered a TGF- $\beta 1$ inhibition. Another study shows that atherosclerosis rapidly tended to progress in mutant mice, one allele of the gene that codes TGF$\beta 1$ of which was removed and the process was regressed through TGF$\beta 1$ infusion. It was observed in another study that the atherosclerotic process progressed faster in the group of mice, which were administered a TGF- $\beta 1$ receptor blocker. In fact, a strong positive correlation with statistical significance $(\mathrm{p}<0.01)$ was 
observed between serum TGF- $\beta 1$ level and coronary artery disease prevalence throughout the oxidative and inflammatory process, the formation of which was indicated, in respect of the patients included in the study.

The oxidized LDL particles that emerge throughout the oxidative process lead to the formation of foam cells. The IL-12, which is secreted from the foam cells so formed, attract $\mathrm{T}$ helper cells and, in to a lesser extent, Treg cells to the intima of the related vascular segment. If the TGF$\beta 1$ cytokines secreted from Treg cells prevail over the proinflammatory cytokines secreted from $\mathrm{T}$ helper cells; the process will tend to progress in favor of the anti-inflammatory cascade, in which case atherosclerosis will either not progress at all or progress to a limited extent in the related vascular segment. Otherwise, atherosclerotic plaque will form and progress.

The most critical determinant in the said competition between IL-12 and TGF- $\beta 1$ is, most certainly, the number of encounters of the two cytokines. It is the oxidized LDL itself that happens to cause and ensure the two cytokines to encounter. The higher the level of oxidized LDL in the medium; the larger the number of macrophages activated is and, thus, the larger the number of $T$ cells drawn to the medium. Since T helpers drawn to the medium would outnumber Treg cells, the process would be expected to tend to progress in the favor of proinflammatory / atherogenic cascade. However, in the event the capacity of the suppressive / immunosuppressive / antiatherogenic effect of the Treg cells drawn to the medium is higher than the overall capacity of the inflammatory / atherogenic effect of the $\mathrm{T}$ helper cells, then macrophage will lose activation, and IL-12 concentration will diminish relatively. On the other hand, the more the number of encounters between Treg cells and $\mathrm{T}$ helper cells, that is the larger the number of oxidized LDLs in the medium; the more likely $\mathrm{T}$ helper cells, which would, in that case outnumber Treg cells, would prevail over Treg cells.

It is believed that the future discovery of conveniently administrable agents with low side effect profile that stimulate Treg cell population and enhance TGF- $\beta 1$ secretion will ensure considerable improvement in the treatment of atherosclerotic coronary artery disease that is the most frequent cause of death at present.

This study is intended to indicate that the sub-clinical inflammation, which emerges on account of such oxidative stress, could be determined by the imbalance between the proinflammatory cytokines (IL-12) and the anti-inflammatory cytokines (TGF- $\beta 1$ ) on the intima of the related vascular segment. 


\section{REFERENCES}

1. World Health Organization: Reducing risks, promoting healty life, Geneva, 2002.

2. Gotsman, A.H. Sharpe, A.H. Lichtman AH. T-cell costimulation and coinhibition in atherosclerosis. Circ Res 2008; 103: 1220-31.

3. Lin J, Li M, Wang Z, He S, Ma $\mathrm{X}, \mathrm{Li} \mathrm{D}$. The role of $\mathrm{CD} 4+\mathrm{CD} 25+$ regulatory $\mathrm{T}$ cells in macrophage-derived foam-cell formation. Lipid Res2010; 51: 1208-17.

4. Vlietstra RE, Kronmal RA, Frye RL, Seth AK, Tristani FE, Killip T. Factors affecting the extent and severity of coronary artery disease in patients enrolled in the coronary artery surgery study. Arterioscler Thromb Vasc Biol 1982; 2: 208-15.

5. Stocker R. Antioxidant defenses in the vascular wall. In: Oxidative Stress and Vascular Disease, edited by Keaney JF Jr. Boston: Kluwer Academic, 1999, p. $27-47$.

6. Fu S, Davies MJ, Stocker R, and Dean RT. Evidence for rolesof radicals in protein oxidation in advanced human atherosclerotic plaque. Biochem J 1998; 333: 519-25.

7. Ridker PM, Silvertown JD. Inflammation, C-reactive protein, and atherothrombosis. J Periodontol 2008; 79: 1544-51.
8. Alizadeh Dehnavi R, de Roos A, Rabelink TJ, van Pelt J, Wensink MJ, Romijn JA et al. Elevated CRP levels are associated with increased carotid atherosclerosis independent of visceral obesity. Atherosclerosis 2008; 200: 41723.

9. Lee TS, Yen HC, Pan CC, Chau LY. The role of interleukin 12 in the development of atherosclerosis in ApoE-deficient mice. Arterioscler Thromb Vasc Biol 1999; 19: 734-42.

10. Hauer AD, Uyttenhove $C$, de Vos P, Stroobant V, Renauld JC, van Berkel TJ, van Snick J, Kuiper J. Blockade of interleukin-12 function by protein vaccination attenuates atherosclerosis. Circulation 2005; 112: 1054-62.

11. Sakaguchi S, Sakaguchi N, Asano M, Itoh M, Toda M. Immunologic selftolerance maintained by activated $\mathrm{T}$ cells expressing IL-2 receptor alphachains (CD25). Breakdown of a single mechanism of selftolerance causes various autoimmune diseases. J Immunol 1995; 155: 1151-64.

12. Robertson AK, Rudling M, Zhou $\mathrm{X}$, Gorelik L, Flavell RA, Hansson GK. Disruption of TGFbeta signaling in $\mathrm{T}$ cells accelerates atherosclerosis. J Clin Invest 2003; 112: 1342-50. 